Revista Eletrônica Geografar, Curitiba, v. 2, Resumos do VI Seminário Interno de Pós-Graduação em Geografia, p. 65-65. Junho/2007

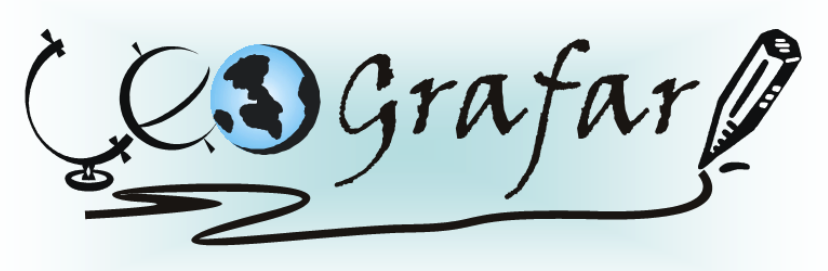

Revista Eletrônica do Programa de Pós-Graduação em Geografia - UFPR

\title{
A DIVERSIDADE GASTRONÔMICA COMO FATOR DE IDENTIDADE CULTURAL NOS CAMPOS GERAIS: POTENCIALIDADES PARA O TURISMO REGIONAL
}

\section{RÚBIA GISELE TRAMONTIN MASCARENHAS ${ }^{1}$}

A gastronomia brasileira deve ser analisada pela sua diversidade, fruto da heterogeneidade cultural, em que a grande riqueza está na diversidade. Assim, a tipicidade da gastronomia regional torna-se um diferencial para destinos turísticos, pois o turismo gastronômico está relacionado às diferenças entre as culturas e as sociedades. No Brasil o turismo gastronômico se baseia nos pratos das cozinhas regionais, nos produtos nacionais e na diversidade de combinações e paladares que foram se estruturando ao longo da formação social brasileira. O presente estudo procura investigar se a unidade regional e a diversidade alimentar presente na Região dos Campos Gerais do Paraná podem representar uma identidade cultural gastronômica, e de que forma, esta pode ser utilizada pela atividade turística. A gastronomia regional nos Campos Gerais apresenta-se como oferta de um produto turístico, porém a demanda real ainda não é mensurável. Sendo assim, torna-se necessário realizar o planejamento baseado nas dimensões e oportunidades que a gastronomia regional apresenta como um produto turístico. Este planejamento deve possuir a capacidade de interlocução entre diversas áreas de conhecimento, considerando como premissa o uso sustentável da atividade turística. A gestão desses destinos deve estar pautada na herança cultural dessa comunidade, no conjunto de valores que determinam sua identidade, proporcionando produtos originais, acessíveis ao turista, e ainda que sejam competitivos, transformando a potencialidade dos destinos em um atrativo turístico.Como metodologia será desenvolvida, pesquisa bibliográfica, estudo exploratório, buscando compreender a diversidade gastronômica regional e uma análise descritiva procurando estabelecer questões conceituais e identificar a alimentação na sociedade dos Campos Gerais. Apresenta-se nos resultados preliminares o uso da gastronomia como atrativo turístico como forma de contribuir para a formação de uma imagem positiva para a região em que é planejada e implantada, resgatando a cultura local e divulgando-a através das atividades turísticas.

Palavras-chave: turismo, gastronomia, identidade regional.

'Doutoranda em Geografia - UFPR - email:rubiatin@uepg.br Orientador: JOSÉ MANOEL GONÇALVES GANDARA 